\title{
ACRL Board actions, June 1991
}

\author{
Highlights of the Annual Conference meeting of the ACRL \\ Board of Directors.
}

$\mathbf{T}$ he Board of Directors of the Association of College and Research Libraries (ACRL) met twice during the ALA Annual Conference in Atlanta: on June 29 and July 1, 1991. Highlights of their actions are as follows:

Awards. Proposals for two new awards were approved. The Bibliographic Instruction Section will recognize an outstanding publication related to bibliographicinstruction. The Rare Books and Manuscripts Section will recognize the author of the best article in Rare Books and Manuscripts Librarianship. Their proposals will be reviewed by the ALA Awards Committee at Midwinter.

Board membership. The chair of the Planning Committee will become an ex-officio member (without vote) of the Board. This change to the ACRL Constitution requires a second Board vote at Midwinter and then will be listed on the spring ALA ACRL ballot.

Continuing education courses. The Board voted that the continuing education courses and plans for regional institutes be discontinued because of poor financial performance. The Board asked the Education Committee to recommend alternative ways to meet the professional development needs of members.

Discussion groups. Two discussion groups petitioned to be dissolved and one group asked to be created. The Microcomputer Services in Academic Libraries and the Extended Campus Library Services discussion groups were dissolved. The Extended Campus Library Services discussion group was reconstituted under the auspices of the Extended Campus Library Services Section. Presenting a petition to form a new group was the discussion group for Exhibits and Displays in Libraries.
FBI. The Board endorsed a resolution commending the $\mathrm{FBI}$ for its cooperation in recovering the 21,000 stolen books and manuscripts found in Stephen Blumberg's house. The resolution was drafted by the Rare Books and Manuscripts Section.

Racial and Ethnic DiversityCommittee. The Board reviewed a preliminary report of the committee's survey on the participation of racial and ethnic groups in ACRL.

Social issues. The Board held an open forum on the question, "How should ACRL respond to social issues?" After the discussion, the Board voted to establish a task force to prepare recommendations on ACRL response or non-response to social issues.

Standards. Revisions to the "Standards for Faculty Status for College and University Librarians" were approved. After approval by the ALA Standards Committee, the standards will be published in a springissue of C\&RL News.

Task forces. Two tasks forces were granted an extension of their terms and two submitted their final reports. The task force on Organizational Members and the task force on the White House Conference on Library and Information Services were both extended until June 1992. The task forces on Faculty Advisory Committee Orientation Materials and Historically Black College and University Libraries both submitted their final reports and were discharged. The Faculty Advisory Task Force's suggestions on developing faculty advisory committee orientation materials will be published in a future issue of $C \& R L$ News.

$E d$. note: See sidebars for president Anne Beaubien's comments on two of the Board's actions. 


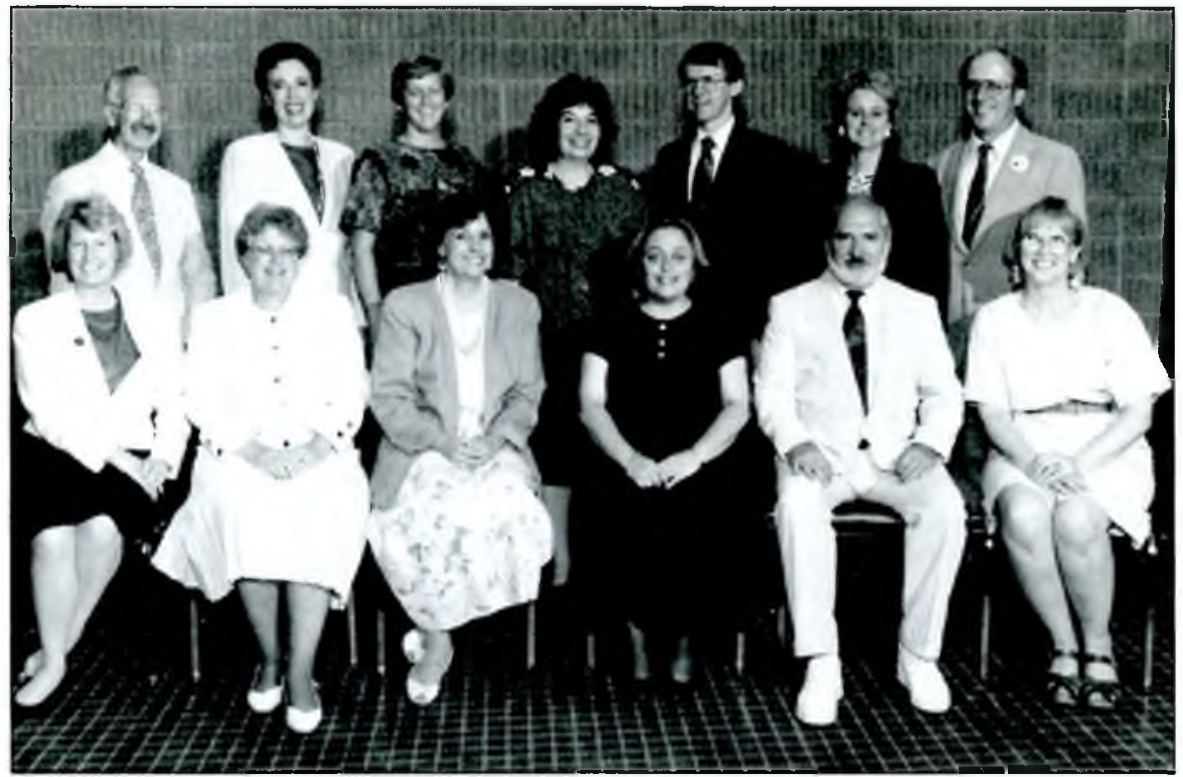

ACRL Board 1990-91. Back row: Evan Ira Farber, Cathleen Bourdon, Shelley E. Phipps, Rochelle Sager, Larry L. Hardesty, Barbara J. Wittkopf, Peter P. Malanchuk. Front row: Leslie A. Manning, Eileen Dubin, Anne K Beaubien, Barbara J. Ford, William A. Moffett, Karin E. Begg.

\section{Task force on social issues appointed}

In the last six months, the ACRL national conference has been moved from Phoenix to Salt Lake City and other cities were considered (see C\&RL News, April 1991). The issues surrounding the site selection of the ACRL National Conference have prompted a gond deal of discussion. The question was raised as to how, and if, our association should respond to social issues.

In order to provide an opportunity for members to discuss the issues, the ACRL Board held an open forum in Atlanta. The forum was broadened from conference site selection to the question, "Should ACRL respond to social issues?" Opinions ranged from "ACRL should respond only to issues related to libraries," to "ACRL should take stands on important social issues."

To address the larger questions, ACRL has created a Social Issues Task Force whose charge is to determine if ACRL should or should not respond to social issues. The Social Issues Task Force will develop a rationale for either case and report its findings to the ACRL Board for consideration at the summer conference in 1992. If the task force feels that ACRL should respond, it will develop a set of guidelines that will guide the ACRL Board in future decisions. The guidelines might include an array of responses that are possible including, but not limited to: moving a conference, publishing position papers, inviting speakers on a topic, etc.

The chair of the Social Issues Task Force is Cerise Oberman, director of libraries at SUNY Plattsburgh. Other task force members at time of writing are Betsy Hine, Carol Rudisell, Bob Martin, Bonnie Clemens, Nancy Bird Luikart, and Pam Cravey. The task force would like to have broad input and I encourage you to write to the chair, Cerise Oberman (Feinberg Library, State Univ. of New York, Plattsburgh, NY 12901; Bitnet: ober macg@snyplava) or any member of the task force with your thoughts on this topic. This is a challenging issue and one that will generate a lot of fruitful discussion and debate. It is an opportunity for us to review ACRL's goals in the context of the world around us.-Anne Beaubien, ACRL President 


\section{ACRL investigates new professional development opportunities}

During our meetings in Atlanta, the ACRL Board decided to investigate new methods of meeting the professional development needs of academic librarians. I have created a Task Force on Professional Development to take a fresh look at the methods for providing continuing education. ACRL has offered various formats for professional development in the past decade. It's time to take stock of what we've done and start planning the best methods for delivery in the 1990s. If you have ideas about the best ways to do this, please contact the chair of the

task force, Meredith Butler, director of University Libraries at SUNY-Albany, 1400 Washington Ave,, Albany, NY 12222-0001. While this investigation is underway, the continuing education courses will not be offered by ACRLin conjunctionwith Annual Conference. ACRL has developed a list of courses and instructors who can be contacted directly by state chapters, library associations, and institutions. Call Cynthia Taylor, (800) 545-2433 ext. 2521 to receive a copy of the list.--Anne Beaubien, ACRLPresident

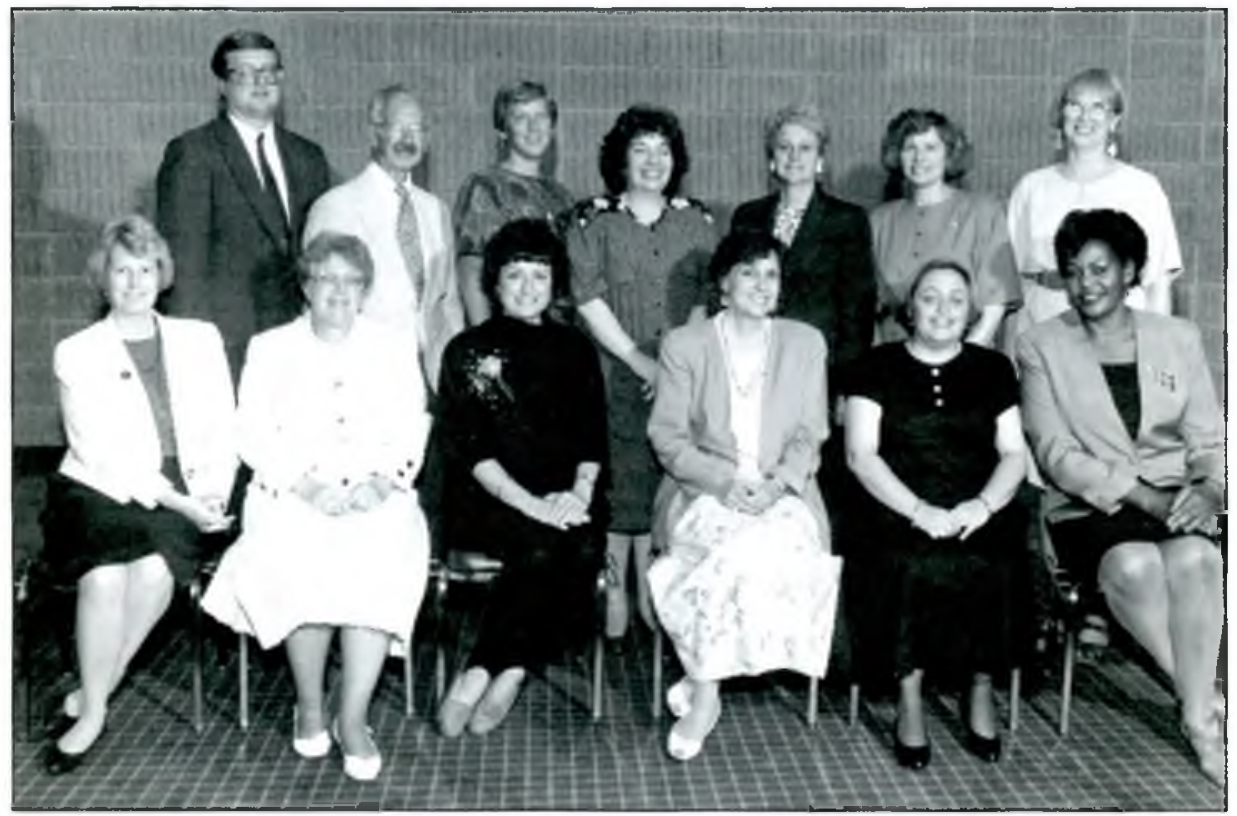

ACRL Board 1991-92. Back row: Ray E. Metz, Evan Ira Farber, Shelley E. Phipps, Rochelle Sager, Barbara J. Wittkopf, Linda L. Phillips, Karin E. Begg. Front row: Leslie A. Manning, Eileen Dubin, Jacquelyn McCoy, Anne K Beaubien, Barbara J. Ford, Althea H. Jenkins.

\section{Multi-year diversity program within ALA staff announced}

Linda F. Crismond, ALA executive director, announced a multi-year program to enhance and appreciate diversity within the ALA staff.

A Diversity in the Work Place Committee has been established to advise on affirmative action recruitment and retention efforts, toprovide leadership to the staff in diversity issues, to serve as a model working across racial and cultural lines, and to participate in identifying and planning training, awareness and celebratory activities at ALA.

"Ourdecision-making process will be enhanced if weencourage input frompeoplewith different points of view and perspective," said Crismond. "Job satisfaction and initiative in the work environment will be improved if respect, trust, appreciation and delegation of responsibility are achieved." 


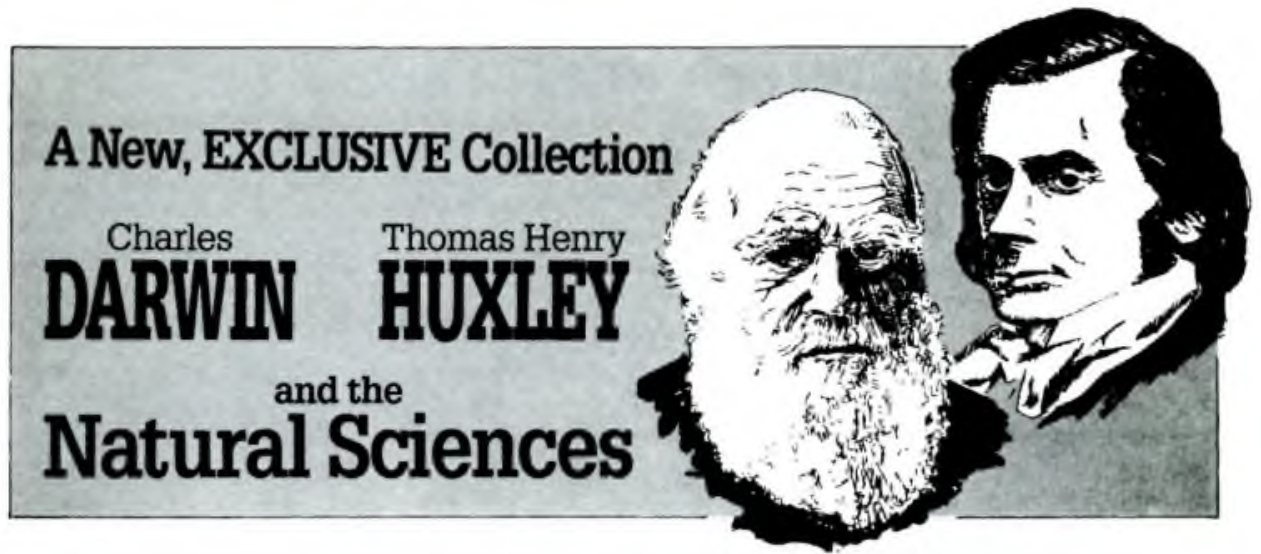

\section{THEIR ORIGINAL MANUSCRIPTS, CORRESPONDENCE AND RARE PRINTED WORKS CAN NOW BE AVAILABLE IN YOUR LIBRARY ON MICROFLM!}

With the addition of this major collection, your library can offer patrons in-depth examination of the original manuscripts of Darwin's landmark treatise, "On the Origin of Species by Means of Natural Selection" and Huxley's shipboard notebooks from the years he sailed on the H.M.S. Rattlesnake studying hydrogoa, oceanic plants and mammals, and performing additional extensive scientific research.

Prior to Research Publications' release of these distinguished papers on microfilm, a scholarly researcher desiring to trace the epochal debate that followed the 1859 publication of "Origin of Species" and Huxley's valiant defense of it, would have had to travel between the Imperial College in London, the University Library, and the Darwin Library at Cambridge University, where this material is located.

This collection of the manuscripts, diaries, lecture notebooks, letters, drawings and personal papers of the two most pre-eminent minds of the 19 th century British scien-

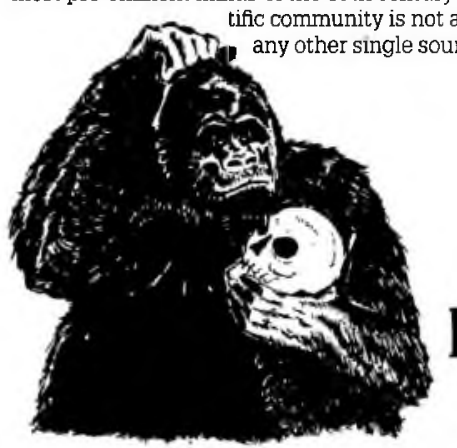

Ip

Now available only from research publications

12 Lunar Drive/Drawer AB

Woodbridge, CT 06525 (203) 397-2600

The Single Most Important Research Collection Documenting Evolutionary Theory

The Charles Darwin Papers include original manuscript versions of "Origin of Specles". "The Movements and Habits of Climbing Plants", "The Descent of Man", his H.M.S. Beagle notebooks, correspondence, contemporary articles and other printed materials substantially annotated by Darwin himself

The Thomas Henry Huxley Papers are an impressive body of material for the study of science during the Victorian era. He was the most resounding defender of Darwin's theories and perhaps the man most responsible for leading Britain's sclentific community to embrace the theory of evolution. His papers give a full, living insight into the many activities in which he took part, provide intriguing details into the personalities of his contemporaries and the affairs of the Royal and leamed societies of his time. Also contained are significant correspondence with Tyndall, Hooker, Michael Foster, Darwin, Lyell Agassiz, Jowett, and Spencer

Open the Door to a School of Classic Scientific Reasoning

"Darwin. Huxley and the Natural Sciences" not only explores evolutionary theory, botany, geology and zoology, but also the historical understanding of the physical world, religion, politics, philosophy and the dawning of the terms "survival of the fittest" and "Social Darwinism"

The addition of this remarkable collection of resource materials to your library will indeed be a prodigious acquisition.

Call Toll-Free 1-800-444-0799 ext 136 Fax 203-397-3893 DON'T FORGET THESE INVALUABLE $\mathbf{P}$ research publications TITLES:

American Natural History American Naturalist
Scientific and Technical Periodicals 17th \& 18th Century Scientific Periodicals 